\title{
New Periodicals of 1966-Part II
}

$\mathrm{T}$ HE YEAR 1966 saw the death of many publications but there seems to be no lack of new journals. Only a few of the new ones can, of course, be mentioned below and it must be remembered that those so mentioned are not necessarily the best or the only ones in their fields.

In the alphabetic listing at the end of this article subscription information, in so far as it could be determined from the publications themselves, has been given. Prices, unless otherwise noted, are annual charges for library subscribers. Library of Congress card numbers have also been included. As in earlier lists, the publications marked by an asterisk have not been annotated in any way as their titles would seem to be sufficient explanation of their contents.

Areas, Regions. The poverty and problems of Appalachia are still much in the news but the Appalachian Review, published by West Virginia University, does not wish to have us lose sight of the really valuable assets of the region. The Review will focus on the worthwhile things of the mountain areas and each issue, in addition to articles on art, crafts, and ways in which the people live, will include a special look at one of the states in the region. The first issue puts the spotlight on North Carolina. Arkansas State reports on an area where there have been many changes and where many changes are expected in the future. The new quarterly will treat a wide variety of subjects (people, places, industry, history) and has many beautiful colored illustrations.

All about Maine, what is right and what is wrong, is promised by Maine Digest. It follows the usual digest format of small size and short articles but is somewhat more heavily illustrated than one might expect.

THE Arts. Although Bells and Bellringing is small and unpretentious its subject matter is most fascinating and it includes material that one certainly cannot find anywhere else. The new quarterly's concern is with the history of bells and it gives much information about the best and the greatest bells and about the people who rang (or played?) them.

Harvard Art Review is "concerned with the discussion and analysis of perception as well as with the field of fine arts." The $R e$ view is not local in character and the first issue includes a number of translations, some from Jean-Paul Sarte. As one might suppose, there are many black and white illustrations. Beautifully colored illustrations are an asset to Southwestern Art. The word "art" in the title is meant to include painting, sculpture, theatre, literature, antiques, coins and currency, architecture, pre-Columbian and Indian antiquities, and many other things. Museums, art schools, and artists of the American West and Southwest will be featured and the editors promise articles and reproductions of heretofore uncataloged and unexhibited paintings by great masters in collections in that part of the country.

Another magazine of the arts, Form, wishes "to publish and provoke discussion of the relation of form to structure in the work of art, and of correspondences between the arts." Emphasis will be placed on the "fields of kinetic art and concrete poetry." Each issue (all librarians take note) will present an author index to and short extracts from a "little" magazine of international interest. Information will be given as to the holdings of the magazine in British and American libraries as well as the approximate cost of microfilm for the complete run. The first issue features Secession, published 1922-24.

Sculpture is claimed to be the "only English periodical on sculpture." It will cover sculpture, painting, architecture, and social environment. The first issue is quite heavily illustrated. Although the text is in English, 
all major articles appear in condensed form in French, Russian, and Spanish.

Books, Libraries. Everything for the book trade (in Germany) is the promise of Buchmarkt. Although it includes much material on new books, it is designed for book dealers and publishers rather than for librarians. It will include information on marketing trends, data processing for those who handle books, and other similar material.

"An annotated guide to current magazines and books," Expanse will, in each issue, describe articles appearing in about one hundred publications (such as Playboy, Time, Reader's Digest). The new biweekly seems to be designed for the personal reader as, in addition to its 10-12 line abstracts, each issue will have a "reading course" on a different subject. The course in the first issue is called "The American Character" and it includes a short bibliography.

Although the publication is small the subject matter of Catalogue \& Index should guarantee interest among librarians everywhere. As the voice of the Library Association's Cataloguing \& Indexing Group, the quarterly will give news of and be an information exchange for cataloging events and ideas in the British library world. It will also include book reviews.

Business, Industry. Mergers of Acquisitions is a hardbound "journal of corporate venture." It will report on tax regulations, pending legislation, and the best times to buy and sell. In addition there will be "how to" articles on merging as well as discussions of mergers that failed. The first issue includes: "Merger Lemons," "Mystique of Antitrust" and "Government Guarantees for Your Investment Abroad."

Reflecting the present interest in all things African, African Development puts emphasis on what Britain can do for Africa and "will be reporting on the financial situation in Britain as it affects Africa, on the capital available, on the latest equipment and services designed for the African market, on the aid situation, on the plans of British firms for new factories in the continent, on the contracts awarded, on the significant journeys of significant people." At the same time, however, developments in
Africa will be studied so that businessmen can understand what commodites are available and how the vast and growing market of Africa can be tapped.

Chase Manhattan Bank's World Business replaces two earlier publications: Latin American Business Highlights and Report on Western Europe. The new bimonthly will include features in depth on areas such as Canada, Oceania, and Africa as well as continue the coverage of its predecessors.

Education. "Teacher-Supervisory Relationships" and "The Role of the Teacher in Educational Decision Making" are two of the articles from the first issue of Changing Education. The quarterly, issued by the American Federation of Teachers, hopes to provide "free and open discussion on topics pertinent to education and social change and to the teacher union movement." Its editors say that "because of our labor union orientation, we will attract and welcome more than the usual proportion of articles that will relate our educational problems and their solutions to the inadequacies of a sick society."

For all who work with exceptional children, the Journal of Special Education is a "multi-disciplinary offering intended as an avenue for communication and interaction among the various disciplines concerned with the education of the exceptional child and with special problems in general education."

General. The Saint Thomas More Political Science Journal is nonprofit and privately published and, although it is not affiliated with any college or university, has an editorial staff made up entirely of undergraduates. It will be a voice for the "conservative reasoning in our youth," those who believe that "America was built upon the firm rock of a fiscally and morally sound government of socio-economic responsibility and not upon the shifting sands of our contemporary governmental operation of "handouts,' red ink, and overburdening commitments in the world state." The first issue includes: "A Program for Civil Rights" and "Viet Nam: Our Manpower Problem-Why Not Mercenaries?"

Another publication which has ideas on the world situation is Discern. In addition to a report on Viet Nam, the first issue has fiction, poetry, and recipes. It, too, would 
seem to be the work of undergraduates although that is not stated anywhere. Louvain Studies is published by the American College of the Immaculate Conception of the Blessed Virgin Mary in Louvain, Belgium, so its articles are mostly the work of priests or those studying for the priesthood and deal with a variety of religious, moral and theological matters.

Career World will provide information on careers for women. In addition to telling of the glamour and advantages of certain occupations, the monthly will give practical information on how to find and get jobs and will carry job-wanted advertisements. Each issue will feature the careers available in a particular city. The first is about Washington and the many opportunities available for those who work for the government.

The editors of Parallel say that they are tired of apologizing for Canada. They wish to create a magazine that will interest Canadians but also one produced in Canada that can, for the first time, interest nonCanadians. Each issue includes poetry, fiction and short pieces on current events and people in the news. Although the periodical is issued in Canada, its material will come from all over the world.

LAw. The University of San Francisco Law Review is another on the always growing list of university law school publications. The articles in the new Review will be written by practicing lawyers but there will be shorter contributions (called "Comments") written by students. The editors of European Transport Law feel that "lawyers and economists are called upon to pool their knowledge in order to attain greater safeguards answering the needs of industry." They feel that the laws and administrative regulations relating to transport must, in this age of space travel and changing frontiers, be reconsidered. The journal is in English, French, German, Dutch, and Italian and the subscription price includes an annual index in the language of the subscriber's choice.

Literature. As always, a number of new "little" magazines have begun publication. Many of them simply appear and their first issues say nothing of what is planned or even of who is doing the planning. Riverrun, for example, is a monthly of poetry and is published in New York. The poets includ- ed in the first issue seem relatively unknown and the magazine does nothing to identify them for the reader. Vagabond, published in Munich, is to be a "literary quarterly of poetry and prose." Most of the contributors to the first issue seem to be Americans studying in Germany. In addition to poetry, the first issue has a short story in the original German followed by an English translation. It is hard to try to predict what type of material future issues will contain.

The University of Denver Quarterly will attempt to exist "between the historical moment of the 'modern' and the still unrealized moment of the 'new.' " It will publish essays, reviews, poetry, and fiction but plans no defense of any particular school, system, or tendency of criticism. West Coast Review, a Canadian literary journal, will include a continuing bibliography of "avantgarde" writing. In the first issue the thirteen-page bibliography is "The Critical Writing on Samuel Beckett." The Review will publish English and French poetry, fiction, and articles on drama, music and art, as well as essays and reviews of books dealing with the arts and creativity.

Another literary quarterly, the Boston Review will publish writing done by New Englanders (anyone born in New England is a New Englander forever) or done in New England. Each issue will feature "an exemplary but unknown writer," the first being Sidney Goldfarb.

Arcadia, a periodical of comparative literary science, does not subscribe to the idea that national literatures should be considered separately. It will be a forum "for all present-day comparative methods" and will also consider those fields (such as the reception of the classical and oriental literatures of antiquity by the national literatures of Europe) which are marginal to its main interests. Although Arcadia intends to include material in English, French, and German, the first issue is entirely in German.

Recreation, Hobbies. For anyone who owns a pet, Pet Fair will contain practical guidance on pet care, information on nutrition, health, grooming, and other such matters. It will include, also, features on famous pets and on the pets of famous people. There will be fiction about animals, humor, photographs, and a special section 
of puzzles, games and stories for small children. "Hatching Tortoise Eggs" and "Trailing Turtles" are two of the articles in the first issue of the International Turtle and Tortoise Society Journal. The society was established for "the conservation of turtles and tortoises of the world" and the Journal will reflect that interest.

"Come let us discourse about fish" (a quotation from Athenaeus) says the editor of Aquarium Illustrated and the new publication does just that. Devoted to the tropical fish hobby, Aquarium will include information on food, species, and equipment and the first issues contain many illustrations. For those who prefer their animals and birds outdoors, Georgia Game \& Fish is issued by the Georgia Game \& Fish Commission to keep its readers informed of the commission's wildlife conservation activities and, also, to increase the pleasure of sportsmen by giving them information on the best methods, times, and locations for hunting and fishing in Georgia.

Directors of the New Hampshire, Vermont, and Maine Aeronautics boards serve as editorial advisors for the Flying Yankee which will be "all about aviation in New England." The Yankee will report on airports, airmen, shows, special flights, and new developments in legislation and safety. For those whose interests are in the water rather than in the air, Ships Monthly will be "concerned with everything nautical, with anchors, guns, and figureheads, as well as with ships in their entirety, and in the literature, art, song, and music of the sea." The first issue includes a pull-out drawing of plans for a British cargo ship as well as articles such as: "Clydeside Clippers of the 1860 's" and "British Destroyers."

The first issue of Antiek, from the Netherlands, contains many beautiful colored illustrations of antiques and, also, a variety of discussions on restoration, collecting, and history of antiques.

ScIEnce. Published in Budapest by the Hungarian Academy of Science, Acta Biochemica et Biophysica is following the worldwide tendency of scientific journals to narrow down their fields of specialization. In the past the results of biomedical research carried on in Hungarian laboratories has appeared in the Academy's Acta Physiologica Academiae Scientiarum Hunga- ricae. The new quarterly will be published in languages, chiefly English, other than Hungarian.

Earth-Science Review will present review articles under four main headings: $A$. Mineralogy, igneous and metamorphic petrology, geochemistry. B. Geophysics, volcanology, geotectonics. C. Sedimentology, paleontology, historical geology. $D$. Economic and applied geology. The quarterly is intended as an international magazine for geoscientists and its articles will carry extensive bibliographies. Earth and Planetary Science Letters is designed to help scientists keep up with current advances. The letter form of publication, in this and other similar journals, means that the articles will be brief and the illustrations few and simple.

In English, French, or German (all with English summaries) the writings in Mineralium Deposita will be concerned with investigations from the fields of geochemistry, mineralogy, physical chemistry and similar subjects. Although published by Springer-Verlag, the new journal is issued under the auspices of the Society for Geology Applied to Mineral Deposits.

Each year the June issue of Oceanology will be a yearbook/directory listing government agencies, companies, and organizations dealing with oceanology as well as aquariums and sources for products and services which are available. The magazine will have feature articles in its subject field as well as editorial reports on topics of current interest. Its editorial advisory board includes such distinguished names as Jacques-Yves Cousteau of Monaco and Allyn C. Vine of Woods Hole.

Desalination, "the international journal of the science and technology of water desalting," appears at a time when there is great interest in its field of investigation. The quarterly will, in addition to scholarly annotated papers, include reviews, news, bibliographical lists, and statistics.

"Japan is of growing importance as one of the world's prime industrial nations but Japanese is outside the linguistic mainstream of the Western world" say the editors of Science and Technology in Japan. In order to communicate with the West, Asahi Evening News is publishing the new quarterly. The first issue is beautifully printed on 
heavy paper and has many illustrations.

Although there are a number of journals reporting areas of interest in the hospital and health care fields none, until the appearance of Health Services Research, has put emphasis on research. The first issue of Research includes articles such as: "Patients' Waiting Time and Doctors' Idle Time in the Outpatient Setting" and "Identification Code for Medical Records."

Social Sciences. Published under the auspices of the University of Wisconsin's Industrial Relations Research Institute, Center for Studies in Vocational and Technical Education, and Institute for Research on Poverty, the Journal of Human Resources will study the effects of education, manpower, and welfare policies in the classroom, the labor market, the community, and in the lives of human beings. Its first issue has articles on: "Supply and Demand for College Teachers" and "Guidelines for Adult and Vocational Research."

PHRA; Poverty and Human Resources Abstracts provides summaries of information from periodicals, pamphlets, books, unpublished working papers, speeches, seminar and research reports, and all other material which the editors and subscribers feel are relevant. Items are organized and crossreferenced under a number of major categories and by geographical area and population type being considered. The bimonthly will appear in a library edition in which each issue is bound in a heavy cover and in a loose-leaf edition in which each item is printed on a single sheet. Each issue will have about fifty abstracts of four hundred to six hundred words, one hundred to two hundred subject annotations (short descriptions of scope and several of the most significant points of finding, methodology, or policy implication) bibliographic references, and a ten to twenty page review article examining a particular aspect of the poverty problem or trends in the field.

Family Perspective, a rather more general perodical than others noted in this section, is intended to stimulate family table-talk, interest, and home research. It is issued by the College of Family Living of Brigham Young University and its first issue examines matters such as: "Utah's Divorce Situation" and "Thiamine Research-Past and Present."
A quarterly review of Latin American studies in the social sciences, Aportes will have one long feature article in each issue as well as a number of shorter articles. Each issue will include a lengthy bibliography.

The Psychoanalytic Forum, issued by the Psychiatric Research Foundation will publish short essays followed by opinions expressed by qualified discussants. The quarterly prefers to limit itself to clinical contributions and discussions of technical aspects rather than going into the realm of theoretical debates. Even the book reviews included will be presented in the form of free discussion representing different ideas and evaluations of new publications.

Roundtables on timely topics (the first is capital punishment) will be included in each issue of An International Journal for Existential Psychiatry, the publication of the American Ontoanalytic Association. In addition to the roundtables and other articles, book reviews and reports on new drugs will be included.

\section{Periodicals}

Acta Biochemica et Biophysica. (Published by Hungarian Academy of Sciences) May be obtained from Stechert Hafner, Inc., 31 East 10th St., New York or Walter J. Johnson, 111 Fifth Ave., New York. v. 1, no. 1, 1966. Quarterly. 165.-F. 66-9947.

African Development. African Development, Ludgate House, Fleet St., London E.C.4. v. 1 , no. 1,1966 . Monthly. $£ 2 / 2 / 0$. 66-9965. Antiek. N. V. Uitgeversmaatschappij 'De Tijdstroom,' Bagijnestraat 11, Lochem, The Netherlands. v. 1 , no. 1 , June/July 1966. 10 no. a year. \& 36,-. 66-9957.

Aportes. Instituto Latinoamericano de Relaciones Internacionales, 23 , rue de la Pépinière, Paris $\left(8^{\circ}\right)$, France. no. 1, July 1966. Quarterly. \$4. 66-9978.

Appalachian Review. West Virginia University, 307 Armstrong Hall, Morgantown, W. Va. 26506. v. 1, no. 1, Summer 1966. Quarterly. \$6. 66-9941.

Aquarium Illustrated. P.O. Box 1214, Cincinnati, Ohio 44201. v. 1, no. 1, Jan./Feb. 1966. Bimonthly. \$2.50. 66-9942.

Arcadia. Walter de Gruyter \& Co., 1 Berlin 30, Genthiner Strasse 13. v. 1, no. 1, 1966. 3 no. a year. DM 42,-. 66-9923.

Arkansas State. Raymond Rebsamen, 1000 Center St., Little Rock, Ark. 72203. v. 1, no. 1, Fall 1966. Quarterly. \$2. 66-9958.

Bells and Bellringing. John Hilton, 19 Lonewood Way, Hadlow, Tonbridge, Kent, Eng- 
land. v. 1, no. 1, May 1966. Quarterly. 3/$66-9956 / \mathrm{MN}$.

The Boston Review. P.O. Box 348, Cambridge, Mass. 02139. v. 1, no. 1, Fall 1966. Quarterly, \$4. 66-9977.

Buchmarkt. Werner-Verlag, 4 Düsseldorf, Adersstrasse 73. 1, 1966. 4 no. a year. DM 25,-. 66-9967.

Career World. Career Publishing Co., 2226 Wisconsin Ave., NW, Washington, D.C. 20007. v. 1, no. 1, Sept. 1966. Monthly. \$4. 66-9948.

Catalogue \& Index. Peter R. Lewis, Queen's University School of Library Studies, 2 College Gardens, Belfast 9, Northern Ireland. no. 1, Jan. 1966. Quarterly. \&1. 66-9924.

Changing Education. American Federation of Teachers, 716 North Rush St., Chicago 60611. v. 1, no. 1, Spring 1966. Quarterly. \$3. 66-9921.

Desalination. Elsevier Publishing Co., P.O. Box 211, Amsterdam, The Netherlands. v. 1, no. 1, Apr. 1966. Quarterly. \$25. 66-9949.

Discern. P.O. Box 259, Fort Collins, Colo. 80521. v. 1, no. 1, Sept./Oct. 1966. Bimonthly. \$2.25. 66-9959.

Earth and Planetary Science Letters. NorthHolland Publishing Co., P.O. Box 103, Amsterdam, The Netherlands. v. 1, no. 1, Jan. 1966. Bimonthly. \$16. 66-9932.

Earth-Science Reviews. Elsevier Publishing Co., P.O. Box 211, Amsterdam, The Netherlands. v. 1, no. 1, Jan. 1966. Quarterly. \$12.50. 669960 .

European Transport Law. Robert H. Wijffels, Advocaat, Justitiestraat 19, Antwerpen (Belgium). v. 1 , no. $1,1966.7$ no. a year. $\$ 35$. 66-9976.

'Europarecht. C. H. Beck'schen Verlagsbuchhandlung, 8 Munchen 23, Wilhelmstrasse 9. v. 1, no. 1, 1966. Quarterly. DM 12.50. 669925.

Expanse. Expanse Publications, Inc., 1330 Jersey Ave. So., Minneapolis, Minn. 55426. v. 1 , no. 1 , Oct. 1965 . Biweekly. \$20. 669966.

Family Perspective. Office of the Dean, College of Family Living, Brigham Young University, Provo, Utah 84601. v. 1, no. 1, Spring 1966. Semiannual. \$2. 66-9961.

The Flying Yankee. Oxford, New Hampshire 03777. v. 1 , no. 1 , Autumn 1966. 10 no. a year. \$3. 66-9943.

Form. 8, Duck End, Girton, Cambridge, Eng. no. 1, Summer 1966. Quarterly. \$2. 66-9950.

Georgia Game \& Fish. Georgia Game and Fish Commission, 401 State Capitol, Atlanta, Ga. 30334. v. 1, no. 1, Oct. 1966. Monthly. \$1. 66-9973.

Harvard Art Review. 620 Quincy House, Harvard University, Cambridge, Mass. 02138. v. 1 , no. 1 , Spring 1966. 3 no. a year. $\$ 3$. 66-9920.

Health Services Research. Hospital Research and Educational Trust, $840 \mathrm{~N}$. Lake Shore Drive, Chicago 60611. v. 1, no. 1, 1966. Quarterly. \$3. 66-9926.

${ }^{\circ}$ High Speed Ground Transportation Journal. International Society for Terrain-Vehicle Systems, Inc., Box 4824, Duke Station, Durham, N.C. 27706. v. 1, no. 1, Jan. 1967. 3 no. a year. \$35. 66-9982.

An International Forum for Existential Psychiatry. Existential Psychiatry, Suite 5908, 300 N. State St., Chicago 60610 (Attn.: Mrs. Jane Jenkins). v. 1, no. 1, Spring 1966. Quarterly. \$8. 66-9936.

- International Journal of Non-Linear Mechanics. Pergamon Press Ltd., 44-01 21st St., Long Island City, N.Y. 11101. v. 1, no. 1, Apr. 1966. Quarterly. \$40. 66-9964.

International Turtle and Tortoise Society Journal. International Turtle and Tortoise Society, Inc., P.O. Box 4555, Los Angeles. v. 1, no. 1, Sept./Oct. 1966. Bimonthly. \$4. 669962.

- Journal of Combinatorial Theory. Academic Press, Inc., 111 Fifth Ave., New York 10003. v. 1 , no. 1 , June 1966. 4 no. a year. $\$ 15$. 66-9963.

The Journal of Human Resources. Journals Dept., University of Wisconsin Press, P.O. Box 1379, Madison, Wisc. 53701. v. 1, no. 1, Summer 1966. Quarterly. \$8. 66-9974.

- Journal of Macromolecular Chemistry. Marcel Dekker, Inc., 95 Madison Ave., New York 10016. v. 1, no. 1, Jan. 1966. Quarterly. $\$ 35.66-9968$.

'Journal of Ocean Technology. Marine Technology Society, 1030 15th St., NW, Washington, D.C. 20005. v. 1, no. 1, June 1966. Semiannual. \$3. 66-9933.

The Journal of Special Education. P.O. Box 455, Fort Washington, Pa. 19034. v. 1, no. 1, Fall 1966. Quarterly. \$10. 66-9979.

Louvain Studies. American College, Naamsestraat 100, Louvain, Belgium. no. 1, Fall 1966. Semiannual. \$1. 66-9919.

Maine Digest. Box 143, Rockport, Maine 04856. v. 1, no. 1, Fall 1966. Quarterly. \$2. 66-9975.

Mergers \& Acquisitions. Mergers \& Acquisitions, Inc., $1725 \mathrm{~K}$ Street N.W., Washington, D.C. 20006. v. 1, no. 1, Fall 1965. Quarterly. $\$ 25$. 66-9930.

Mineralium Deposita. .Springer-Verlag, 69 Heidelberg, 1, Postfach 3027. v. 1, no. 1, May 1966. 4 no. a year. $\$ 24$. 66-9918.

Oceanology. Industrial Research, Inc., Beverly Shores, Ind. 46301. v. 1, no. 1, June 1966. 7 no. a year. $\$ 5$. 66-9927.

-Oral Research Abstracts. American Dental As- 
sociation, 211 East Chicago Ave., Chicago 60611. v. 1, no. 1, Apr. 1966. Monthly. $\$ 30$. $66-9951$.

'Organizational Behavior and Human Performance. Academic Press, 111 Fifth Ave., New York 10003. v. 1, no. 1, Sept. 1966. Quarterly. \$24. 66-9952.

PHRA; Poverty and Human Resources Abstracts. Managing Editor, PHRA. University of Michigan, P.O. Box 1567, Ann Arbor, Mich. 48106. v. 1, no. 1, Jan./Feb. 1966. Bimonthly. \$30. (loose-leaf); $\$ 40$. (bound). 66-9955.

Parallel. Parallel Publications, Inc., 1110 Sherbrooke St. West, Montreal, Quebec, Canada. v. 1, no. 1, Mar./Apr. 1966. Bimonthly. $\$ 3.50$. 66-9934.

Pet Fair. 1224 W. Van Buren, Chicago 60607. v. 1, no. 1, Aug. 1966. Monthly. \$6. 66-9928.

-Physiology \& Behavior. Pergamon Press, 122 East 55th St., New York 10022. v. 1, no. 1, Jan. 1966. Quarterly. \$30. 66-9937.

The Psychoanalytic Forum. Managing Editor, The Psychoanalytic Forum, 9629 Brighton Way, Beverly Hills, Calif. 90210. v. 1, no. 1, 1966. Quarterly. \$25. 66-9929.

-Reviews in Macromolecular Chemistry. Marcel Dekker, Inc., 95 Madison Ave., New York 10016. v. 1 , no. 1,1966 . Semiannual. $\$ 14.50$. 66-9971.

Riverrun. 27 1st Ave., Apt. 13, New York. v. 1 , no. 1 , Oct. 1966. Monthly. $\$ 5$. 66-9980.

The Saint Thomas More Political Science Journal. c/o Edward J. Kanarkowski, Editor, 264 Bayside Drive, Highlands, N.J. 07732. v. 1, no. 1, Winter 1966. 3 no. a year. Free. 669983.

Science and Technology in Japan. C.P.O. Box 555, Tokyo, Japan. v. 1, no. 1, 1966. Quarterly. $\$ 3.50$. 66-9917.

Sculpture International. Studio International, 43 Gold St., Northampton, Eng. no. 1, Jan. 1966. Quarterly. Price not given. 66-9953.

Ships Monthly. Endlebury Publishing Co., Ltd., Grosvenor Road, London, E10, Eng. v. 1, no. 1, Jan. 1966. Monthly. \$5.50. 669938.

Southwestern Art. P.O. Box 1763, Austin, Tex. 78701. v. 1, no. 1, Spring 1966. Quarterly. $\$ 6.66-9954$.

The University of Denver Quarterly. The University of Denver, Denver, Colo. 80210. v. 1, no. 1, Spring 1966. Quarterly. \$4. 66-9939.

The University of San Francisco Law Review. University of San Francisco, Law Review, Kendrick Hall, University of San Francisco, San Francisco, Calif. 94117. v. 1, no. 1, Oct. 1966. Semiannual. \$5. 66-9972.

Vagabond. Gollierstrasse 5, 8 Munich 12, Germany. v. 1, no. 1, Jan./Mar. 1966. Quarterly. \$1. 66-9946.

West Coast Review. The Editor, West Coast Review, Simon Fraser University, Burnaby 2, B.C., Canada. v. 1 , no. 1, Spring 1966. 3 no. a year. \$3. 66-9940.

World Business. Chase Manhattan Bank, N.A., Economic Research Division, New York 10015. no. 1, July 1966. Bimonthly. Price not given. 66-9935. 